\title{
Guest Editorial Philosophy of Science in Practice and Practical Realism
}

Endla Lõhkivi

Rein Vihalemm

Department of Philosophy, University of Tartu

\section{Background of the workshop}

Most of the papers in this special issue of Studia Philosophica Estonica are based on the presentations at the international workshop "Practical Realism - Towards a Realistic Account of Science" held at the University of Tartu, 15-17 June, 2011. The workshop was organised by the Chair of Philosophy of Science in the framework of a research project supported by the Estonian Science Foundation's grant-system (grant no 7946, 2009-2012, grant holder, Professor Rein Vihalemm). The grant-project entitled "Constructive realism in the conception of models-based scientific theory" initially tackled the concept of scientific theory and models in the new situation of contemporary philosophy of science, which can be characterised by the focus shifting away from the theory because it has been recognised as an unjustifiably narrow orientation on theoretical physics only, at the same time neglecting the research of a more general issue of "how science actually works". As a result of our research, we suggest a solution to the problem via developing a version of model-based constructive realism we call practical realism which exhibits clear advantages over other constructivist approaches, especially over constructive empiricism and "radical" social constructivism. For the different members of our research group, the specific research areas have been diverse extending from physics (two theoretical physicists have been participating in our team) and chemistry to social researches and humanities.

In our previous publications we have shown that for understanding the real practice of science, it is appropriate to adopt practical realism as the philosophical point of departure. Practical realism has been characterised

Corresponding author's address: Endla Lõhkivi, Department of Philosophy, Institute of Philosophy and Semiotics, University of Tartu, Ülikooli 18, Tartu, 50090, Estonia. Email: endla.lohkivi@ut.ee. 
and analysed in its various specific aspects, including an analysis of its historical origins, the accounts of scientific theory and concept in philosophy of chemistry, the issue of monism and pluralism for understanding science, the problem of laws of nature in non-classical science, the Kuhnian conception of science, the theoretical issues related to the Sociology of Scientific Knowledge (SSK), the problems related to measurement practices, criticism of standard empiricism based on history of scientific practice, etc. Through participation in the international co-operation projects, some empirical studies of science as practice have been undertaken. For instance, in the EU 6th framework programme project UPGEM, the workplace cultures and the institutional dynamics of Estonian physics research units have been explored. Specifically, the aim was to explain how the inclusion and exclusion mechanisms of ideas, people and working styles are culturally formed and how this is relevant for the philosophical analysis of the objectivity standards of scientific knowledge. ${ }^{1}$

At our university, the philosophy of science research group consists mainly of philosophers with a background in science. We have been investigating several philosophical issues of scientific practices for many years. However, it was the first time we organised an international workshop dedicated specifically to the theoretical view we call practical realism. Our intention was to discuss the philosophical background of our approach and some preliminary results of the research project with a broader circle of philosophers who are holding and developing an account of science as practice. While until the last decades of the 2oth century only few philosophers paid attention to the actual history of science, and even less to the particular practical experimental settings or cultural contexts, by now, the situation has radically changed due to the naturalist and practical turn in philosophy. The empirical aspects of the development and functioning of science have been increasingly taken into account in philosophy of science, as well as in other areas of philosophy. Philosophy has given up its previously superior position and become a true ally to all academic disciplines. Since practical realism as a position involves both questions of theoretical and empirical significance, theoretical as well as empirical papers analysing scientific practice were welcomed to the workshop.

\section{What is practical realism?}

When inviting colleagues to the workshop we characterised our view of practical realism by reference to five main theses of practical realism: ${ }^{2}$

1 See (Lõhkivi 2011), (Velbaum et al. 2008).

2 See (Vihalemm 2005, 180-181), (Vihalemm 2011a, 104), (Vihalemm 2011b, 48). 
1. Science does not represent the world "as it really is" from a god's-eye point of view. Naïve realism and metaphysical realism have assumed the god'seye point of view, or the possibility of one-to-one representation of reality, as an ideal to be pursued in scientific theories, or even as a true picture in the sciences.

Representationalism, however, is a tricky view since we lack independent criteria for judging the accuracy of a representation. Either external criteria or additional assumptions are needed, which makes the view implausible.

2. The fact that the world is not accessible independently of scientific theories-or, to be more precise, paradigms (practices)-does not mean that Putnam's internal realism or "radical" social constructivism is acceptable.

In his work Reason, Truth, and History (1981), Putnam suggested that in the sciences we actually address reality via our internal conceptual schemes. Radical social constructivism suggests that scientific objects are socially constructed and do not exist independently of the construction.

Both of these views are controversial. Internal realism is inconsistent in the sense that it is not realism of any kind, although the title presumes that, and social constructivism in this radical form appears to be self-refuting, since social constructivist views are constructions as well. On the practical level, the radical social constructivist view contradicts common sense-one simply cannot do anything one wants to, as reality resists.

3. Theoretical activity is only one aspect of science; scientific research is a practical activity and its main form is the scientific experiment that takes place in the real world, being a purposeful and critical theory-guided constructive, as well as a manipulative, material interference with nature.

Thus, from the practical realist perspective practice is not inferior to theory, theories are construed as sets of models, and model construction is a natural part of research practices.

4. Science as practice is also a social-historical activity, which means, amongst other things, that scientific practice includes a normative aspect, too. That means, in turn, that the world, as it is accessible to science, is not free of norms either.

Therefore, according to this view, it is justified to study the researchers' identities, division of labour, organisation of work and relations within the wider cultural contexts.

5. Though neither naïve nor metaphysical, it is certainly realism, as it claims that what is "given" in the form of scientific practice is an aspect of the real world. Or, perhaps more precisely, science as practice is a way in which we are engaged with the world.

This is the way Joseph Rouse (1987) has proposed to interpret Thomas 
S. Kuhn's concept of paradigm: through paradigms we are in touch with the world.

All papers presented at the workshop addressed these theses in one or another way.

\section{The Contributors}

To the workshop we invited philosophers who have been contributing to the philosophy of science in practice. As one of our keynote speakers, we invited an outstanding author in the naturalised approach, Professor Joseph Rouse from Wesleyan University, CT, USA, the author of How Scientific Practices Matter: Reclaiming Philosophical Naturalism (2002); Engaging Science: How to Understand its Practices Philosophically (1996); and Knowledge and Power: Towards a Political Philosophy of Science (1987). His talk at our workshop was titled as "Articulating the World: Conceptual Understanding and the Scientific Image". A paper based on this talk is forthcoming as "Articulating the World: Experimental Practice and Conceptual Understanding," in Isabelle Peschard and Bas van Fraassen (eds.), The Experimental Side of Modeling, Chicago: University of Chicago Press.

The other keynote speaker was Professor Rom Harré from Georgetown University, USA, and the Oxford Linacre College, and the Centre for Philosophy of Natural and Social Science, LSE, UK. Author of more than thirty books, Harré has been studying, amongst other topics, the cultural aspects of science, emphasising that it is not theories but scientists who refer to scientific objects. Interestingly, Harré has found inspiration in the idea of Umwelt developed by the Baltic German biologist and alumnus of the University of Tartu (then Dorpat), Jakob von Uexküll. According to Harré, we should interpret scientists' activities via their life-world or Umwelt. This, of course, applies to all human activities, and it is particularly interesting to see how the sciences, in their turn, influence our Umwelt.

We were also very glad to host other guest speakers: Hanne Andersen from Aarhus University in Denmark; Sami Pihlström from the Universities of Helsinki and Jyväskylä, Finland; Rafaela Hillerbrand from RWTH Aachen, Germany; Peeter Müürsepp from Tallinn University of Technology; Jean-Pierre Llored from CREA/Ecole Polytechnique, France; and Evaldas Juozelis from Mykolas Romeris University in Vilnius, Lithuania.

On the part of the organisers, Rein Vihalemm, Endla Lõhkivi together with her PhD students Katrin Velbaum and Jaana Eigi, Ave Mets and Michiru Nagatsu gave a talk. It is worth noting that as the practice turn in philosophy of science can be and has been associated with Thomas S. Kuhn's name, several contributors to the workshop (Hanne Andersen, Joseph Rouse, Sami Pihlström, Rein Vihalemm) reflected upon his views in their presentations. 
Another interesting feature of the workshop was chemistry as a subject matter providing good examples for the analysis of the practical nature of science - as it was emphasised by R. Vihalemm - thus it would not come as a surprise that several participants have a background in chemistry or some connections with it: Jean-Pierre Llored is a chemist who has become a philosopher of science; the authors of this foreword - Rein Vihalemm and Endla Lõhkivi have their first degrees in chemistry; Rom Harré is among other things interested in philosophy of chemistry and he is the honorary President of the International Society for the Philosophy of Chemistry. Also, Peeter Müürsepp, whose background is in mathematics, has written on philosophy of chemistry; and Sami Pihlström, whose main interest is pragmatism, is also contributing to the book edited by Jean-Pierre Llored on philosophy of chemistry. But, in connection to pragmatism, it deserves to be mentioned that its founder Charles Sanders Peirce had a background in chemistry.

At the workshop, many novel theoretical approaches and interesting case studies were presented, the discussions were highly inspiring and interesting. The feedback from the participants has been very positive and strongly encouraging for future research on the topic. Most of the papers presented at the workshop have been revised in the light of the discussion and the referee comments, and are now published in this volume. We would like to thank all the authors and referees for their excellent work.

\section{Acknowledgments}

For their kind support of our workshop, we would like to thank the Doctoral School of Linguistics, Philosophy and Semiotics, the British Council, the Embassies of the US and France, and the Estonian Science Foundation (grant nos. 7946 and 7163). Also, our thanks go to Mats Volberg, the managing editor of Studia Philosophica Estonica for his help and advice in the editing process.

\section{Bibliography}

Lõhkivi, E. (2011). Identity and rationality: Towards normative cultural studies of science, Baltic Journal of European Studies 1: 97-110.

Velbaum, K., Lõhkivi, E. and Tina, M.-L. (2008). UPGEM national report: Estonia, Draw the Line! Universities as workplaces for male and female researchers in Europe, Tartu University Press, Tartu, pp. 137-212.

Vihalemm, R. (2005). Chemistry and a theoretical model of science: On the 
occasion of a recent debate with the Christies, Foundations of Chemistry 7: 171-182.

Vihalemm, R. (2011a). The autonomy of chemistry: Old and new problems, Foundations of Chemistry 13: 97-107.

Vihalemm, R. (2011b). Towards a practical realist philosophy of science, Baltic Journal of European Studies 1: 46-6o. 